\section{Genotypic Variation of Morphological Traits in Tall Fescue (Festuca arundinacea Schreb.) Accessions}

\author{
Yanhong Lou \\ College of Agronomy, Hunan Agricultural University, Nongda Road, ChangSha \\ City, Hunan 410128, P.R. China; and Key Laboratory of Plant Germplasm \\ Enhancement and Specialty Agriculture, Wuhan Botanical Garden, Chinese \\ Academy of Sciences, Wuhan City, Hubei 430074, P.R. China
}

\section{Liang Chen}

Key Laboratory of Plant Germplasm Enhancement and Specialty Agriculture, Wuhan Botanical Garden, Chinese Academy of Sciences, Wuhan City, Hubei 430074, P.R. China

\section{Qingguo $\mathbf{X u}^{1}$}

College of Agronomy, Hunan Agricultural University, Nongda Road, ChangSha City, Hunan 410128, P.R. China

\section{Xunzhong Zhang ${ }^{1}$ \\ Crop \& Soil Environmental Science, Virginia Polytechnic Institute and State University, Balcksburg, VA 24060 \\ Additional index words. tall fescue, morphological traits, genetic variation, correlation analysis}

\begin{abstract}
Tall fescue is an important cool-season grass widely used for forage and turf, and its genotypic variation for morphological traits has not been well documented. One hundred and fifteen tall fescue accessions, including 25 commercial cultivars, were divided into five groups based on their origination. The morphological traits, including plant height, spike length, pulvinus distance, spikelet count, branch count per spike, spike count per plant, and spike weight in different accessions were determined under field conditions in 2013 and 2014. There was significant genotypic variation in morphological traits among the 115 tall fescue accessions. Wild accessions exhibited a greater variation in the morphological traits than commercial cultivars. Close correlations were found among plant height, spike length, pulvinus distance, and spikelet count. The results of this suggest plant height, spike length, pulvinus distance, and spikelet count could be used as key morphological traits for evaluating all fescue germplasm effectively.
\end{abstract}

Tall fescue (Festuca arundinacea Schreb.), a cross-pollinated, hexaploid, cool-season perennial grass, has been widely grown as an important forage and turf grass throughout the world (Aiken and Strickland, 2013; Seal, 1983). The grass belongs to the tribe Festuceae, subfamily Festucoideae, and family Poaceae (Seal, 1983). Natural populations are distributed in temperate and cool climates throughout Europe, North-West Africa, North America, and west and central Asia (Černoch et al.,

Received for publication 3 Dec. 2014. Accepted for publication 23 Jan. 2015.

We thank the United States Department of Agriculture-Agricultural Research Service (USDA-ARS) for providing tall fescue germplasm. This work was financially supported by Key laboratory of Plant Germplasm Enhancement and Specialty Agriculture, Wuhan Botanical Garden, Chinese Academy of Sciences (Grant No. Y052811t04).

${ }^{1}$ To whom reprint requests should be addressed; e-mail huxu0309@aliyun.com or e-mail xuzhang@ vt.edu. tall fescue cultivars was currently being lost due to severe genetic erosion associated with overgrazing, irregular rainfall, and the loss of rangeland in Tunisia. Majidi et al. (2009) indicated that morphological variation in tall fescue germplasm was heritable, and that several traits including plant height and dry matter yield had a high narrow sense heritability value. Morphological traits are of great importance in selecting rational parents for hybridization breeding of many crops. The knowledge of genotypic diversity was indispensable for efficient utilization of genetic resources and breeding (Beyene et al., 2006; Finger et al., 2010).

Plant height, spike length, spikelet count, spike count per plant, and spike weight are major components of plant yield as selection criteria in breeding (Topal et al., 2004). Ebrahimiyan et al. (2012) reported significant genotypic variation in plant height, flag-leaf length, and flag-leaf width among the seventy five tall fescues. The variation of morphological traits was influenced by genotype and environment (Chtourou-Ghorbel et al., 2011). Niazkhani et al. (2014) observed that the plant height had lower direct and positive effect on dry forage yield (correlation coefficient equals to 0.051 ). Knowledge of relationship among the morphological traits was the basic and most important for plant selection in a breeding program (Hasan et al., 2013).

Leaf roughness, poor regeneration ability, and poor stress resistance limit wide utilization of tall fescue (Carrow, 1996; Cross et al., 2013; Xu et al., 2006). Excellent tall fescue cultivars are not only able to produce more biomass, but also survive stress conditions. Fortunately, there was tongs of tall fescue germplasm composed of landraces, commercial cultivars, and breeding lines ( $\mathrm{Li}$ et al., 2010). Thus, improvement of tall fescue might encourage its use as a forage grass species (Easton et al., 1994). However, genetic variation in morphological traits of tall fescue has not been understood very well.

Describing the morphological traits of a large tall fescue collection is still costly and time-consuming. Selecting and describing numerous traits within smaller sample was reasonable and possible. The objectives of this study were to investigate the phenotypic variation of the morphological characteristics and to determine the correlation between the morphological traits. The findings of this study would add new information for better understanding the genetic diversity of tall fescue and therefore facilitate breeding design.

\section{Materials and Methods}

Plant materials and growth conditions. The present research was conducted at Wuhan Botanical Garden, Chinese Academy of Science, Wuhan, China from 2012 to 2014. The climate in this region is of a northern subtropical type, with a warm, humid summer, and an obvious altitudinal change. Maximum, minimum, and mean annual temperature was $29.3{ }^{\circ} \mathrm{C}$ in July and August, $0.4^{\circ} \mathrm{C}$ in January, and $17.5{ }^{\circ} \mathrm{C}$ respectively. The 


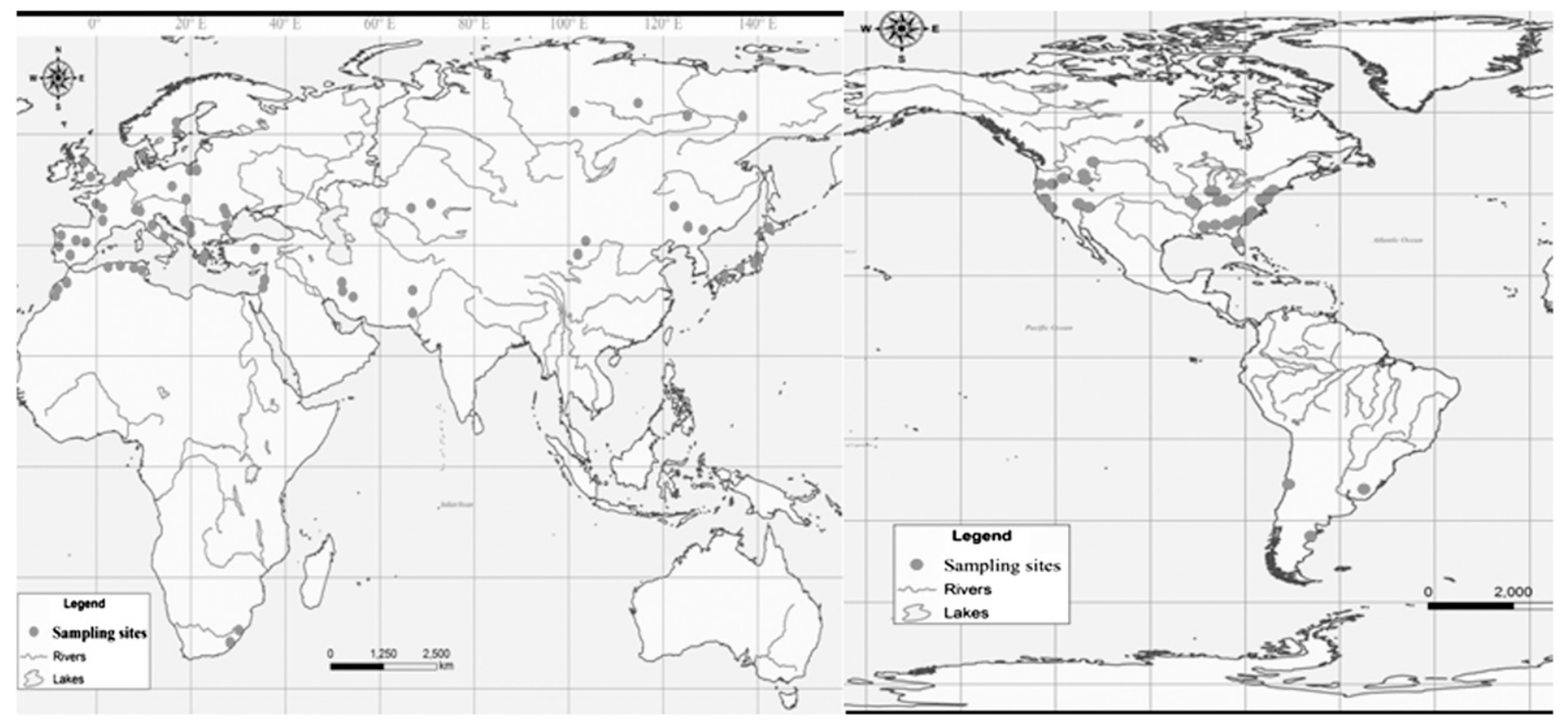

Fig. 1. Geographical origin of 115 tall fescue accessions used in this study.

Table 1. Tall fescue accession and their geographical origin used in this study.

\begin{tabular}{|c|c|c|c|c|c|}
\hline & & Accession & & & $\begin{array}{c}\text { Geographica } \\
\text { origin }\end{array}$ \\
\hline$\overline{\mathrm{AST}}-1$ & Firenza & Matador & Coyote II & Pixie & Cultivar \\
\hline SH 3 & Rembrandt & SR 8650 & Tomahawk GT & Grand II & \\
\hline Tahoe II & Lindergh & LS-11 & 3rd Millennium & Smirna & \\
\hline Justice & Millennium & Endeavor & Stone wall & Silverado II & \\
\hline ATM & Barlexas & Wolfpack & Davinci & Focus & \\
\hline PI 574522 & PI 531230 & PI 203728 & PI 508603 & PI 596701 & America \\
\hline PI 636597 & PI 578717 & PI 578718 & PI 583822 & PI 578724 & \\
\hline PI 634238 & PI 655112 & PI 655113 & PI 578719 & PI 559374 & \\
\hline PI 561430 & PI 469244 & PI 578714 & PI 601106 & PI 601227 & \\
\hline PI 601447 & PI 608024 & PI 608025 & PI 632516 & PI 608787 & \\
\hline PI 600739 & PI 600801 & PI 538006 & PI 608808 & PI 427127 & \\
\hline PI 538330 & & & & & \\
\hline PI 512305 & PI 512315 & PI 610933 & PI 577082 & PI 598496 & Europe \\
\hline PI 577094 & PI 598930 & PI 527504 & PI 423090 & PI 422638 & \\
\hline PI 598491 & PI 598493 & PI 636601 & PI 504538 & PI 577081 & \\
\hline PI 442490 & PI 231563 & PI 234881 & PI 234883 & PI 235036 & \\
\hline PI 235125 & PI 249738 & PI 257742 & PI 274617 & PI 283281 & \\
\hline PI 283304 & PI 311044 & PI 184041 & PI 255874 & PI 283287 & \\
\hline PI 423045 & PI 595072 & & & & \\
\hline PI 636532 & PI 598860 & PI 610909 & PI 610951 & PI 208679 & Africa \\
\hline PI 208681 & PI 224975 & & & & \\
\hline PI 655104 & PI 502373 & PI388897 & PI 547396 & PI 598574 & Asia \\
\hline PI 388898 & PI 619025 & PI 269894 & PI 440345 & PI 438521 & \\
\hline PI 499494 & PI 499495 & PI 174210 & PI 200339 & PI 211032 & \\
\hline PI 505833 & PI 618971 & PI 618973 & PI 619005 & PI 380844 & \\
\hline
\end{tabular}

mean annual precipitation was $1347.7 \mathrm{~mm}$. The mean annual sunshine duration was 1450-2050 $\mathrm{h}$. The tall fescue accessions used in this study consisted of landraces and commercial cultivars. The distribution and origin of the 115 tall fescue accessions, including 25 commercial cultivars, were listed in Figure 1 and Table 1 . The accessions were divided into five groups based on origination (i.e., Cultivar, America, Europe, Africa, and Asia).

A single seed from each accession was initially placed on a layer of filter paper which soaked water in petri dishes in May, 2012. The petri dishes were placed in the dark at $20{ }^{\circ} \mathrm{C}$ until germination, and then transferred to 300-500 $\mu \mathrm{mol}$ photons per $\mathrm{m}^{-2} \cdot \mathrm{s}^{-1}$ natural sunlight for $14 \mathrm{~h}$ photoperiod. After 2 weeks, all accessions were transferred to plastic containers (15 $\mathrm{cm}$ deep and $14 \mathrm{~cm}$ diameter) filled with a mixture of cultivation medium and sand $(1: 1, \mathrm{v} / \mathrm{v})$. Each accession was cloned multiple times by tillers to maintain genetic uniformity. All accessions were established in a walk-in growth room with daily maximum and minimum temperature of 24 and $20^{\circ} \mathrm{C}$, with a 14-h photoperiod and light intensity of $300 \mu \mathrm{mol}$ photons per $\mathrm{m}^{-2} \cdot \mathrm{s}^{-1}$, respectively. They were watered daily to maintain well watered conditions, and fertilized weekly with one-half strength Hoagland's solution (Hoagland and Arnon, 1950). The grasses were mowed weekly to $7 \mathrm{~cm}$ canopy height.
In Sep. 2012, the experimental plots were fertilized with $49 \mathrm{~kg} \mathrm{~N} / \mathrm{ha}, 98 \mathrm{~kg}$ P/ha, and 98 $\mathrm{kg} \mathrm{K} / \mathrm{ha}$. Peat soil (2-cm thick) was applied, and then the soil was subjected to deep-tillage $(25-30 \mathrm{~cm})$, raked for smoothness, and then covered with sand (2-cm deep). The 115 accessions were transplanted to the experimental field in a $1.5 \times 1.5 \mathrm{~m}$-lattice in Oct. 2012. The fertilizer with the ratio of N:P:K at 21:6:13 was applied in Mar. 2013 to provide $49 \mathrm{~kg} \mathrm{~N} / \mathrm{ha}$. The tall fescue was fertilized monthly from April through November in 2013 with $49 \mathrm{~kg} \mathrm{~N} /$ ha compound fertilizer and urea. After the data were collected in 13 June 2013, the grasses were mowed to the height of $10 \mathrm{~cm}$, and no mowing was conducted at other times during the whole experimental stage. In 2014, the tall fescue was fertilized at $49 \mathrm{~kg} \mathrm{~N} / \mathrm{ha}$ each time in April and May with compound fertilizer and urea. Data were collected on 28 May and 7 June in 2014. The experimental field was irrigated as needed to prevent from wilt in 2 years. When irrigated, water was applied to wet the entire root zone. The experimental sites were syringed occasionally during sunny, rain-free periods.

Measurements. Data were collected on the plant height, spike length, pulvinus distance, spikelet count, branch count per spike, spike count per plant, and spike weight from 4 June to 13 June in 2013 and from 28 May to 7 June in 2014.

Plant height was determined as the distance from the ground level to tip of a plant. Seven uniform plants from accession per replicate were measured and the average was used for statistical analysis. Spike length was defined as the distance from the bottom to the tip of spike. Four plants with an average size from each accession per plot were measured and the average was used for analysis.

Pulvinus distance was the distance from main spike neck to flag leaf pulvinus. Four plants with an average size from each 
accession per plot were measured and the average was used for analysis.

The spikelet, branch per spike, and spike per plant was counted from four plants with an average size from each accession per plot, and the average was used for statistical analysis.

Spike weight was determined from four plants with an average size from each accession per plot. An average of four plants was used for analysis.

Statistical analysis. The experiment was arranged in a completely randomized block design with four replications. All data were averaged over 2 years and subjected to the analysis of variance for accession effects using the general linear model procedure of SPSS software version 13 (SPSS Inc., Chicago, IL) (Norusis, 1998). The simple correlation coefficient between the morphological traits was calculated using Person correlation coefficient by SPSS software version 13 (SPSS Inc.) (Norusis, 1998). The analysis of variance was used to assess the effects of accessions on morphological traits. Mean separations were performed using Fisher's protected least significant difference test $(P \leq 0.05)$.

\section{Results and Discussion}

The analysis for two phenotypic data (Supplemental Table 1) showed that there was no significant difference in these evaluated traits between 2 years, and therefore the average value of phenotypic data for 2 years was used for subsequent analysis. The seed yield was closely associated with spike count per plant and spike weight (Klepo et al., 2013). Therefore, excellent parental material was key factors for breeding high yield cultivars. The results in this study indicated that frequency distributions of morphological traits exhibited a normal distribution among all accessions (Fig. 2). Spike count per plant $(55.68 \%)$ and spike weight (48.28\%) exhibited a greater coefficient of variation $(\mathrm{CV})$ than other traits. In contrast, branch count per spike showed a little CV (13.93\%) (Fig. 2). Plant height, spike length, pulvinus distance, and spikelet count had a similar CV.

Significant variation in CV of morphological traits was also observed among accessions from different geographic regions (Table 2). The same results were observed in perennial ryegrass (Lolium perenne) (Bugge, 1987) and tall fescue (Sun et al., 2014). Wild tall fescue accessions had a greater CV than commercial cultivars. This was consistent with previous reports which demonstrated that morphological and agronomical variability in wild populations was greater than commercial cultivars (Belaj et al., 2010; Lumaret et al., 2004; Sun et al., 2014). Simmonds (1993) reported that plant breeding often reduced genetic variation in crop species. In addition, Africa tall fescue accessions had the lowest $\mathrm{CV}$ in most functional traits, and followed by
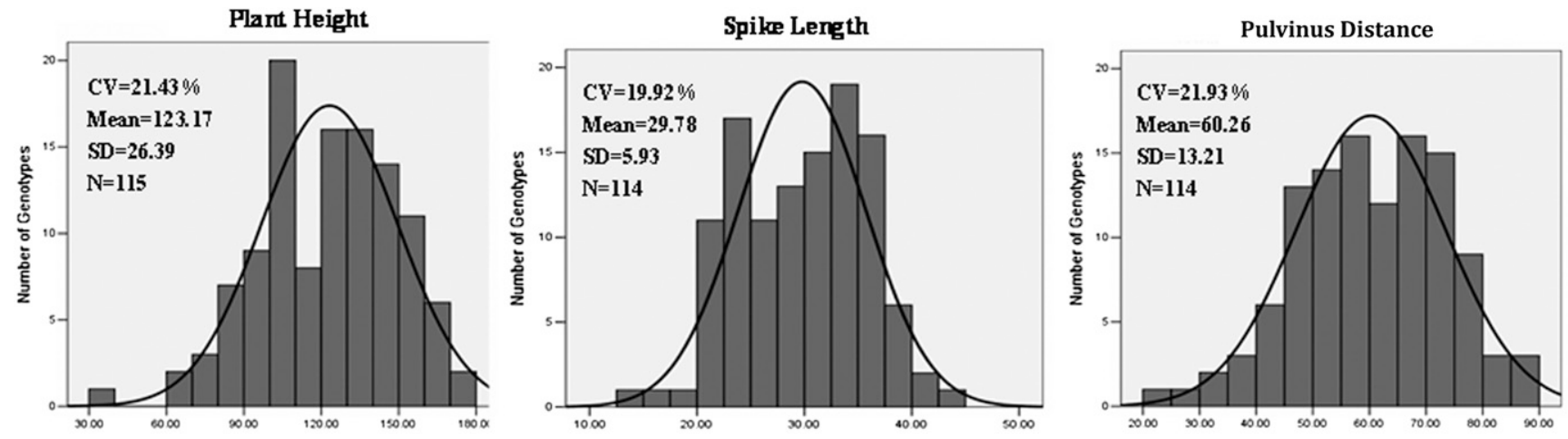

Spikelet Caunt
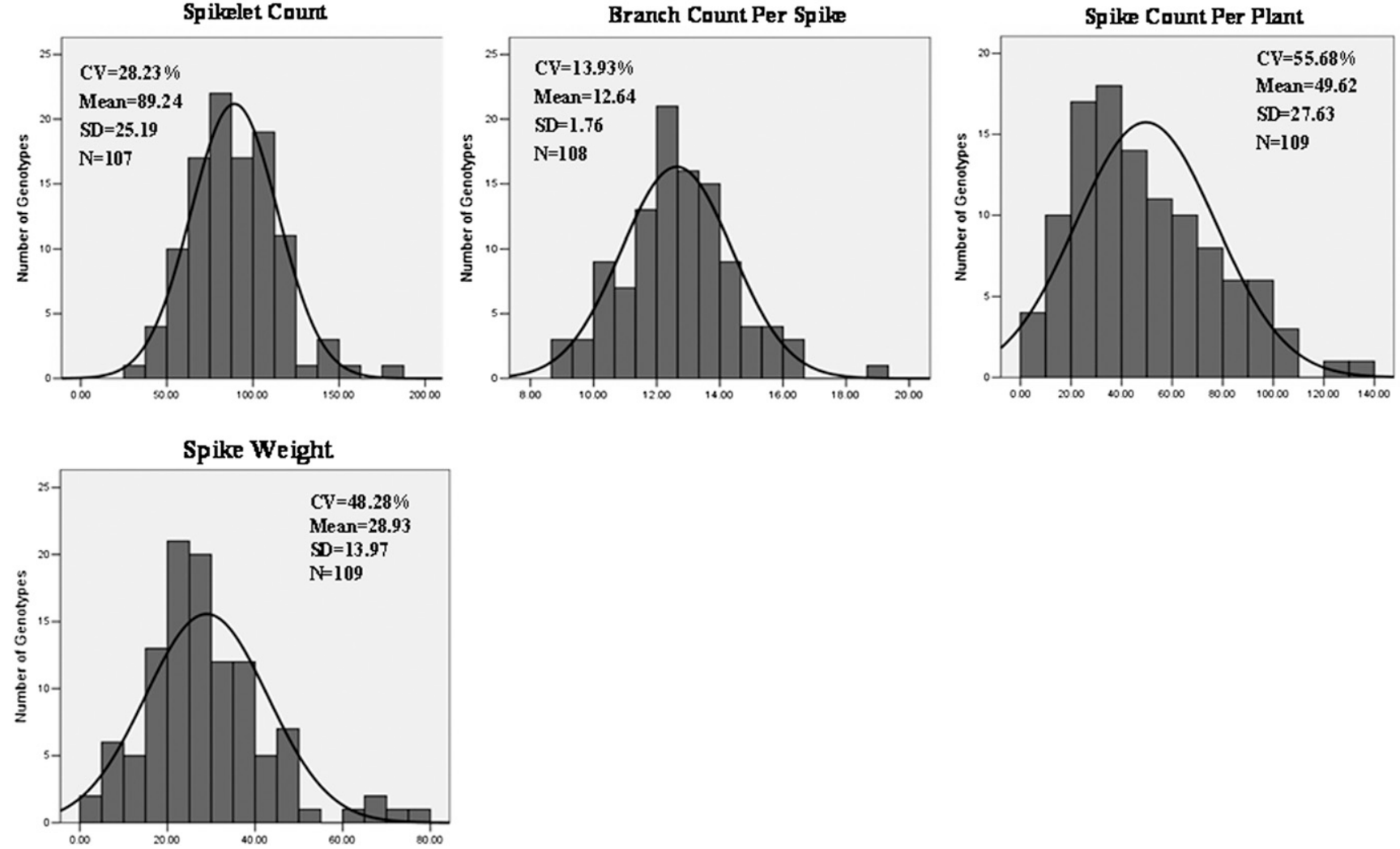

Fig. 2. Frequency distribution in morphological traits of tall fescue accessions. 
wild accessions from Europe and Asia. The lowest $\mathrm{CV}$ in the Africa group might be attributed to the limited accessions (only seven accessions were observed).

The average spike count per plant in wild groups was generally lower than that in commercial cultivar group (Table 4). Tall fescue accessions in the Asia group had the least spike count. There was no significant difference in spike length among the wild groups (America, Europe, Africa, Asia group). Tall fescue accessions from the Africa generally had greater plant height (1.38-fold) and pulvinus distance (1.47-fold) when compared to the commercial cultivar group. The Asia accessions had a longer spike (1.35-fold), more spikelet (1.30-fold), and branch (1.30-fold) per spike, respectively, when compared to the commercial cultivar group. The spike weight in America accessions was 1.17-fold higher than that in the commercial cultivar group.

The evaluation of the genetic variation among the tall fescue cultivars, the first step in description of tall fescue germplasm, was crucial for their conservation and utilization (Gowda et al., 2012; Smith and Smith, 1989; Smith et al., 1991). The genetic variation has been investigated in many other plants, such as rice (Oryza sativa L.) (Chakanda et al., 2013), maize (Zea mays L.) (Couto et al., 2013), wheat (Triticum aestivum L.) (Li et al., 2012), and pea (Pisum sativum L.) (Jha et al., 2013). These results revealed that high diversity in morphological traits could be a useful tool for germplasm collection.

One morphological trait could be used to predict another morphological trait based on their correlation. Morphological traits are important components for the characterization of tall fescue accessions (Skinner et al., 1999). Correlation analysis showed that plant height was significantly correlated to spike length $(r=0.734)$, pulvinus distance $(r=$ $0.810)$, spikelet count $(r=0.308)$, and spikelet weight $(r=0.338)$ (Table 3). Spike length was also correlated with most traits we observed except for spike count, with $r$ value ranging from 0.247 to 0.757 . Pulvinus distance also had significant correlations with plant height $(r=0.810)$, spike length $(r=$ $0.757)$, spikelet count $(r=0.252)$, spike weight $(r=0.300)$. Spikelet count had significant correlations with branch count per spike $(r=0.532)$, spike length $(r=0.493)$, plant height $(r=0.308)$, pulvinus distance $(r=0.252)$. Spikelet count was negatively correlated with spike count per plant, with $r$ value of 0.250 . Similar result was also found in wheat (Triticum aestivum L.) by Ding et al. (2011) who showed that spikelet count was negatively correlated with spike count per plant. Additionally, spike count per plant had no significant correlation with most traits except for spike weight. There was a significant correlation between spike weight and spike count per plant $(r=0.567)$. The understanding of the relationship between the observed morphological traits is essential to the effective design in breeding strategy, and could facilitate the tall fescue breeding (Ahmadikhah et al., 2008; Milatović et al., 2010; Norman et al., 2011).

In summary, there was a significant genotypic variation in morphological traits among tall fescue accessions. Spike count per plant and spike weight exhibited much

Table 2. Variation coefficient of morphological traits of tall fescue accessions from different regions.

\begin{tabular}{lccccccc}
\hline & $\begin{array}{c}\text { Plant } \\
\text { height }\end{array}$ & $\begin{array}{c}\text { Spike } \\
\text { length }\end{array}$ & $\begin{array}{c}\text { Pulvinus } \\
\text { distance }\end{array}$ & $\begin{array}{c}\text { Spikelet } \\
\text { count }\end{array}$ & $\begin{array}{c}\text { Branch count } \\
\text { per spike }\end{array}$ & $\begin{array}{c}\text { Spike count } \\
\text { per plant }\end{array}$ & $\begin{array}{c}\text { Spike } \\
\text { weight }\end{array}$ \\
\hline Cultivar (25 accessions) & 10.43 & 12.92 & 15.76 & 26.57 & 14.85 & 52.78 & 45.89 \\
America (31 accessions) & 21.86 & 19.41 & 16.85 & 26.38 & 9.82 & 37.87 & 49.74 \\
Europe (32 accessions) & 19.20 & 15.29 & 20.76 & 28.09 & 16.70 & 64.43 & 47.86 \\
Africa (7 accessions) & 16.63 & 11.55 & 15.75 & 22.73 & 5.85 & 34.76 & 35.31 \\
Asia (20 accessions) & 24.19 & 18.57 & 25.45 & 28.09 & 8.79 & 58.79 & 49.55 \\
\hline
\end{tabular}

Table 3. Person correlation coefficients among plant height, spike length, pulvinus distance, spikelet count, branch count per spike, spike count per plant, and spike weight for 115 tall fescue accessions.

\begin{tabular}{lcccccc}
\hline & $\begin{array}{c}\text { Spike } \\
\text { length }\end{array}$ & $\begin{array}{c}\text { Pulvinus } \\
\text { distance }\end{array}$ & $\begin{array}{c}\text { Spikelet } \\
\text { count }\end{array}$ & $\begin{array}{c}\text { Branch count } \\
\text { per spike }\end{array}$ & $\begin{array}{c}\text { Spike count } \\
\text { per plant }\end{array}$ & $\begin{array}{c}\text { Spike } \\
\text { weight }\end{array}$ \\
\hline Plant height & $0.734^{* *}$ & $0.810^{* *}$ & $0.308^{* *}$ & 0.158 & 0.055 & $0.338^{* *}$ \\
Spike length & & $0.757^{* *}$ & $0.493^{* *}$ & $0.367^{* *}$ & -0.083 & $0.247^{* *}$ \\
Pulvinus distance & & & $0.252^{* *}$ & 0.146 & 0.081 & $0.300^{* *}$ \\
Spikelet count & & & & $0.532^{* *}$ & $-0.250^{* *}$ & $0.200^{*}$ \\
Branch count per spike & & & & & -0.182 & -0.009 \\
Spike count per plant & & & & & & $0.567^{* *}$ \\
\hline
\end{tabular}

count per plant

**Significant at $P=0.01$ (two-tailed).

* Significant at $P=0.05$ (two-tailed).

Table 4. Average value of morphological traits of tall fescue accessions from different regions.

\begin{tabular}{lccccccc}
\hline Accession & $\begin{array}{c}\text { Plant } \\
\text { height }(\mathrm{cm})\end{array}$ & $\begin{array}{c}\text { Spike } \\
\text { length }(\mathrm{cm})\end{array}$ & $\begin{array}{c}\text { Pulvinus } \\
\text { distance }(\mathrm{cm})\end{array}$ & $\begin{array}{c}\text { Spikelet } \\
\text { count }\end{array}$ & $\begin{array}{c}\text { Branch count } \\
\text { per spike }\end{array}$ & $\begin{array}{c}\text { Spike count } \\
\text { per plant }\end{array}$ & $\begin{array}{c}\text { Spike } \\
\text { weight }(\mathrm{g})\end{array}$ \\
\hline Cultivar & 103.4 & 23.6 & 49.5 & 77.9 & 11.8 & 62.9 & 27.6 \\
America & 129.1 & 31.4 & 64.3 & 88.8 & 12.6 & 54.9 & 32.4 \\
Europe & 127.2 & 31.5 & 62.4 & 93.1 & 13.1 & 44.4 & 29.3 \\
Africa & 142.5 & 31.4 & 72.7 & 86.5 & 11.5 & 41.8 & 30.9 \\
Asia & 125.5 & 31.8 & 59.7 & 101.5 & 13.5 & 29.5 & 21.5 \\
\hline
\end{tabular}

greater $\mathrm{CV}$. With regard to the geographic origin of tall fescue, wild tall fescue generally had a greater $\mathrm{CV}$ in most traits than commercial cultivar group. The correlation analysis showed that plant height, spike length, pulvinus distance, and spikelet count were highly correlated with each other. The variance of one trait is strongly dependent on the other traits. These findings might be considered as important for the characterization of tall fescue accessions.

\section{Literature Cited}

Ahmadikhah, A., S. Nasrollanejad, and O. Alishah. 2008. Quantitative studies for investigating variation and its effect on heterosis of rice. Intl. J. Plant Prod. 2:297-308.

Aiken, G.E. and J.R. Strickland. 2013. Forages and pastures symposium: managing the tall fescuefungal endophyte symbiosis for optimum forage-animal production. J. Anim. Sci. 91:2369-2378.

Belaj, A., C. Muñoz-Diez, L. Baldoni, Z. Satovic, and D. Barranco. 2010. Genetic diversity and relationships of wild and cultivated olives at regional level in Spain. Sci Hort. 124:323-330.

Beyene, Y., A.M. Botha, and A.A. Myburg. 2006. Genetic diversity in traditional Ethiopian highland maize accession assessed by AFLP markers and morphological traits. Biodivers. Conserv. 15:2655-2671.

Bonos, S.A., B.B. Clarke, and W.A. Meyer. 2006 Breeding for disease resistance in the major cool-season turfgrasses. Annu. Rev. Phytopathol. 44:213-234.

Bugge, G. 1987. Selection for seed yield in Lolium perenne L. Plant Breed. 98:149-155.

Carrow, R. N. 1996. Drought avoidance characteristics of diverse tall fescue cultivars. Crop Sci. 36:371-377.

Černoch, V., I. Našinec, and P. Šrámek. 2003. Share of grasslands on landscape forming in the Czech Republic. Czech J. Genet. Plant 39:158162.

Chakanda, R., R. van Treuren, B. Visser, and R. van den Berg. 2013. Analysis of genetic diversity in farmers' rice varieties in Sierra Leone using morphological and AFLP $^{\circledR}$ markers. Genet. Resour. Crop Ev. 60:1237-1250.

Chtourou-Ghorbel, N., M. Chakroun, H. Elazreg, and N. Trifi-Farah. 2011. Agronomic evaluation and genetic variation of Tunisian tall fescue (Festuca arundinacea Schreb.). Intl. J. Agron. 2011:1-6.

Couto, E.G. de. O., L.M.C. Davide, F. de. O. Bustamante, R.G.V. Pinho, and T.N. Silva. 2013. Identification of haploid maize by flow cytometry, morphological and molecular markers. Ciênc Agrotec. 37:25-31.

Cross, J.W., S.A. Bonos, B.R. Huang, and W.A. Meyer. 2013. Evaluation of heat and drought as components of summer stress on tall fescue genotypes. HortScience 48:1562-1567.

Ding, A.M., J. Li, F. Cui, C.H. Zhao, H.Y. Ma, and H.G. Wang. 2011. Correlation analysis on yield related traits and quality traits of wheat using two associated RIL population. J. Triticeae Crops (In Chinese). 31:480-486

Dutta, P., P.N. Dutta, and P.K. Borua. 2013. Morphological traits as selection indices in rice: A statistical view. Univ. J. Agr. Res. 3:85-96.

Easton, H.S., C.K. Lee, and R.D. Fitzgerald. 1994. Tall fescue in Australia and New Zealand. New Zeal. J. Agr. Res. 37:405-417.

Ebrahimiyan, M., M.M. Majidi, and A. Mirlohi. 2012. Genotypic variation and selection of traits related to forage yield in tall fescue under 
irrigated and drought stress environments. Grass Forage Sci. 68:59-71.

Finger, F.L., S.D. Lannes, A.R. Schuelter, J. Doege, A.P. Comerlato, L.S.A. Goncalves, F.R.A. Ferreira, L.R. Clovis, and C.A. Scapim. 2010. Genetic diversity of Capsicum chinensis (Solanaceae) accessions based on molecular markers and morphological and agronomic traits. Genet. Mol. Res. 9:1852-1864.

Gowda, S.J.M., G.J. Randhawa, I.S. Bisht, P.K. Firke, A.K. Singh, Z. Abraham, and B.S. Dhillon. 2012. Morpho-agronomic and simple sequence repeat-based diversity in colored rice (Oryza sativa L.) germplasm from peninsular India. Genet. Resour. Crop Ev. 59:179189.

Hasan, M.J., M.U. Kulsum, A. Akter, A.S.M. Masuduzzaman, and M.S. Ramesha. 2013. Genetic variability and character association for agronomic traits in hybrid rice (Oryza Sativa L.). Bangladesh J. Pl Breed Genet. 24:45-51.

Ha, S.B., F.S. Wu, and T.K. Thorne. 1992. Transgenic turf-type tall fescue (Festuca arundinacea Schreb.) plants regenerated from protoplasts. Plant Cell Rpt. 11:601-604.

Hoagland, D.R. and D.I. Arnon. 1950. The waterculture method for growing plants without soil. In: California agricultural experiment station, Circ 347, 2nd ed.

Jha, A.B., G. Arganosa, B. Tar'an, A. Diederichsen, and T.D. Warkentin. 2013. Characterization of 169 diverse pea germplasm accessions for agronomic performance, Mycosphaerella blight resistance and nutritional profile. Genet. Resour. Crop Ev. 60:747-761.

Klepo, T., R. De. La. Rosa, Z. Satovic, L. Lorenzo, and A. Belaj. 2013. Utility of wild germplasm in olive breeding. Sci Hort. 152:92-101.
Li, H.Y., Y.H. Lou, T. Hu, and J.M. Fu. 2010. Genetic diversity analysis of Chinese natural tall fescue (Festuca arundinacea) germplasms by RAPD. Acta Prata Sinca (In Chinese). 19:208-214.

Li, X.J., X. Xu, X.M. Yang, X. Q. Li, W.H. Liu, A.N. Gao, and L.H. Li. 2012. Genetic diversity among a founder parent and widely grown wheat cultivars derived from the same origin based on morphological traits and microsatellite markers. Crop Pasture Sci. 63:303-310.

Lumaret, R., N. Ouazzani, H. Michaud, G. Vivier, M.F. Dequilloux, and F. Di Giusto. 2004. Allozyme variation of oleaster populations (wild olive tree) (Olea europaea L.) in the Mediterranean Basin. Heredity 92:343-351.

Majidi, M.M., A. Mirlohi, and F. Amini. 2009. Genetic variation, heritability and correlations of agro-morphological traits in tall fescue (Festuca arundinacea schreb.). Euphytica 167:323-331.

Milatović, D., D. Nikolić, and D. Durović. 2010. Variability, heritability and correlations of some factors affecting productivity in peach. Hort. Sci. 37:79-87.

Niazkhani, S.M., B.M. Zanjani, M. Zeynali, S. Ahmadpour, and A.R. Eivazi. 2014. Assessing of morph-physiological traits in tall fescue (Festuca arundinacea schreb.) germplasms. Basic Res. J. Agr. Sci. Rev. 3:1-5.

Norman, P.E., P. Tongoona, and P.E. Shanahan. 2011. Determination of interrelationships among agro-morphological traits of yams (Dioscorea spp.) using correlation and factor analyses. J. Appl. Biosci. 45:3059-3070.

Norusis, M. J. 1998. SPSS/PC Advanced Statistics. SPSS Inc, Chicago, United States.

Seal, A.G. 1983. DNA variation in Festuca. Heredity 50:225-236.
Simmonds, N.W. 1993. Introgression and incorporation. Strategies for the use of crop genetic resources. Biol. Rev. 68:539-562.

Skinner, D.Z., G.R. Bauchan, G. Auricht, and S. Hughes. 1999. A methods for the efficient management and utilization of large germplasm collection. Crop Sci. 39:1237-1242.

Smith, J.S.C. and O.S. Smith. 1989. The description and assessment of distances between inbred lines of maize: the utility of morphological, biochemical and genetic description and a scheme for the testing of distinctiveness between inbred lines. Maydica 34:151-161.

Smith, S.E., A. Al-Doss, and M. Warburton. 1991. Morphological and agronomic variation in North African and Arabian alfalfas. Crop Sci. 31:11591163.

Sun, X.Y., L.X. Hu, Y. Xie, and J.M. Fu. 2014. Evaluation of genotypic variation in heat tolerance of tall fescue by functional traits. Euphytica 199:247-260.

Topal, A., C. Aydin, N. Akgün, and M. Babaoglu. 2004. Diallel cross analysis in durum wheat (Triticum durum Desf.): identification of best parents for some kernel physical features. Field Crops Res. 87:1-12.

Wang, B. and Y.Z. Xie. 2007. Progress of stress physiology of Festuca arundinacea. J. Agr. Sci. (In Chinese). 28:56-60.

Wang, Z.Y., A. Hopkins, and R. Mian. 2001. Forage and turf grass biotechnology. Crit. Rev. Plant Sci. 20:573-619.

Xu, S., J.L. Li, X.Q. Zhang, H. Wei, and L.J. Cui. 2006. Effects of heat acclimation pretreatment on changes of membrane lipid peroxidation, antioxidant metabolites, and ultrastructure of chloroplasts in two cool-season turfgrass species under heat stress. Environ. Expt. Bot. 56:274-285. 
Supplemental Table 1. Values of morphological traits of tall fescue accessions.

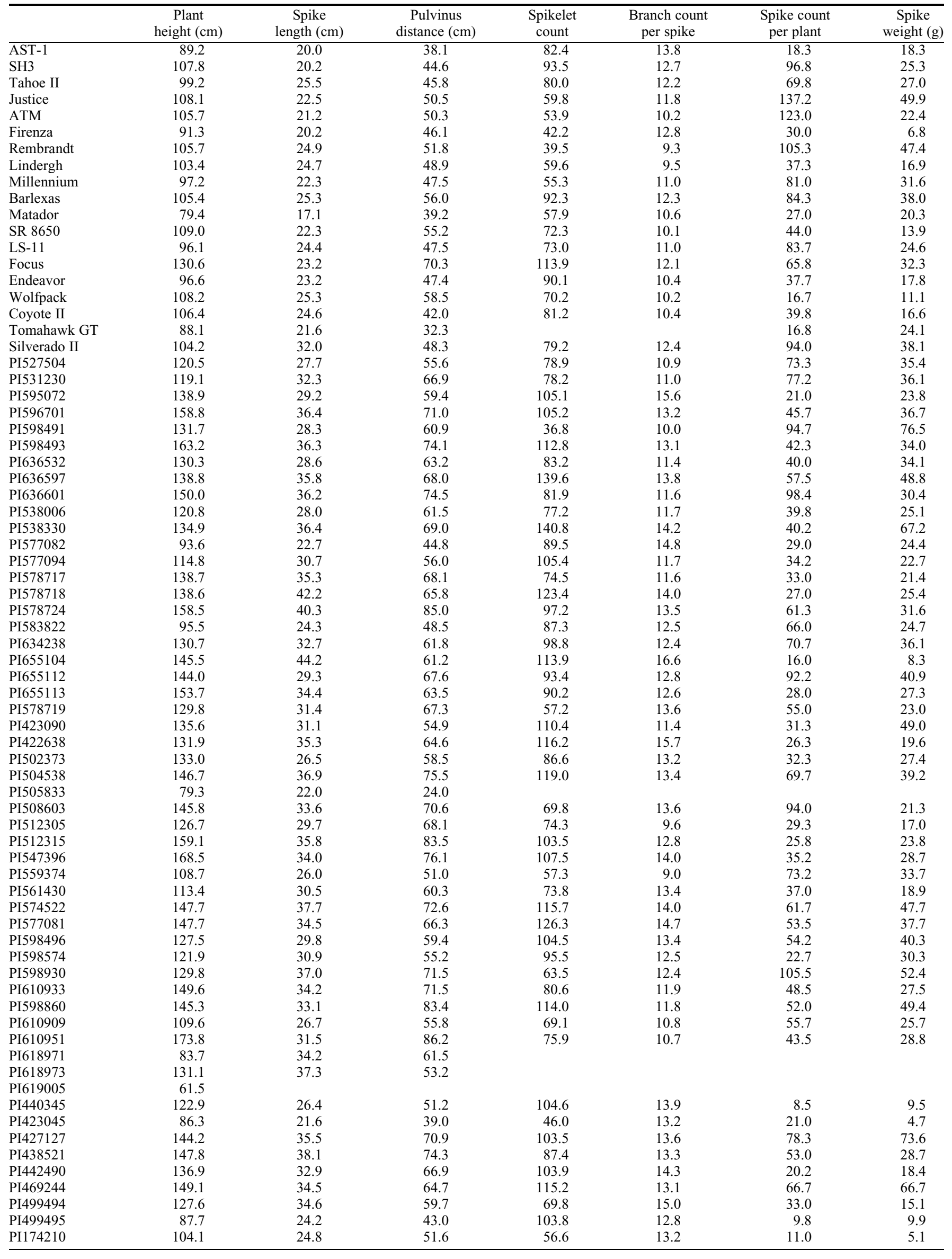

(Continued on next page) 
Supplemental Table 1. (Continued) Values of morphological traits of tall fescue accessions.

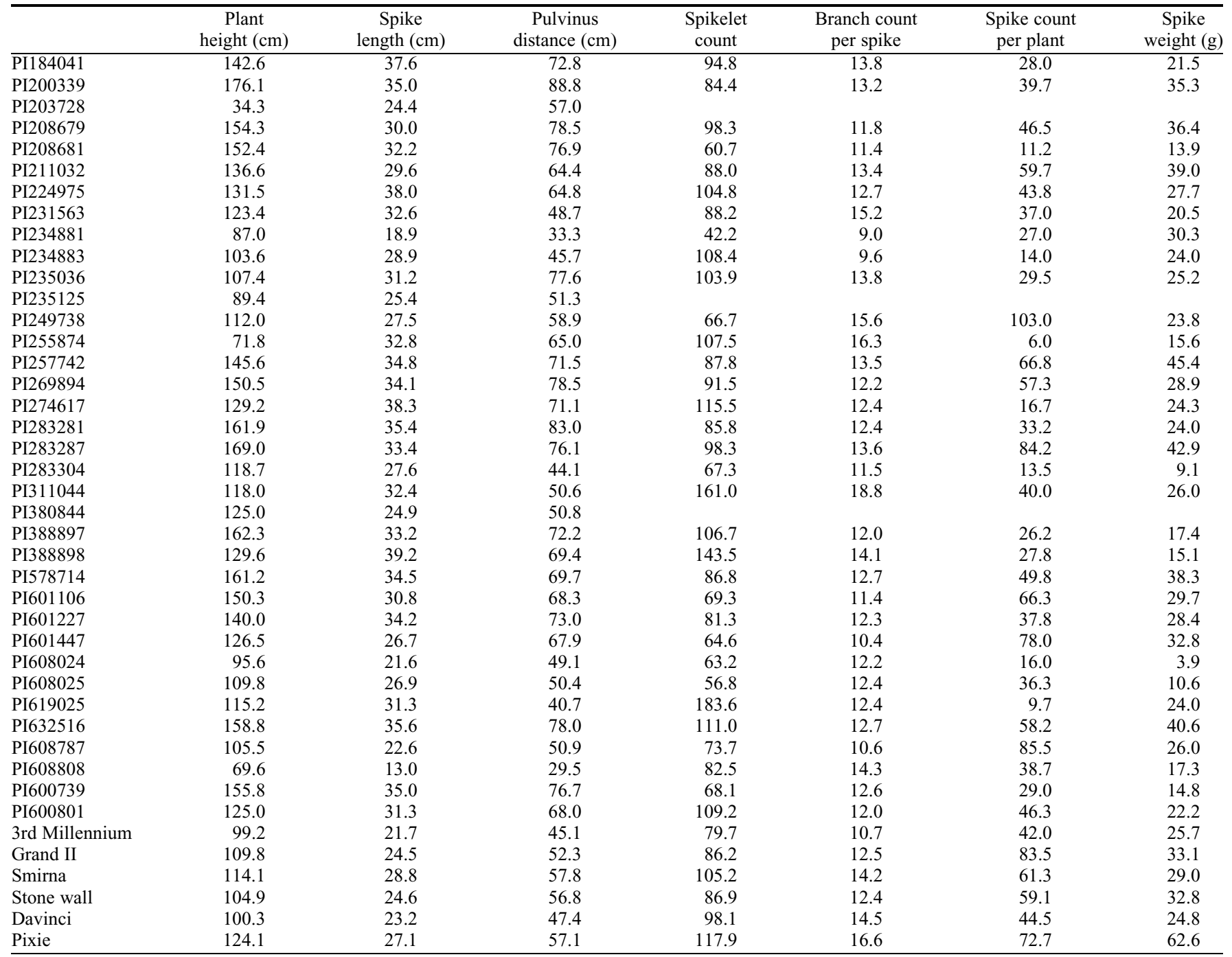

